\title{
Perception on Flood Impact and Source of Employment of Farmers in Flood Affected Areas of Assam
}

\author{
A. $\operatorname{Rahman}^{1 *}$ and S. Barman ${ }^{2}$ \\ ${ }^{1} R A R S$, TItabar, AAU, Jorhat-13, India \\ ${ }^{2}$ Department of Extension Education, FA AAU, Jorhat-13, India \\ *Corresponding author
}

\section{A B S T R A C T}

The present study was conducted in two districts of Upper Brahmaputra Valley Zone of Assam namely Jorhat and Majuli district in order to assess the socio-economic profile of flood affected farmers, their employment status and perception on flood impacts. A total of 160 farmers were selected from eight villages of two districts by following proportionate cum random sampling techniques. The findings reveal that majority of the respondents were in between 41-59 years of age with education level upto class VII standard and having 4-6 members in their family with average annual income Rs.7,339.00. Most of the

Keywords

Employment status,

Perception,

Flood impact

Article Info

Accepted:

07 June 2019

Available Online:

10 July 2019

respondents were small farmers with 13-32 years of farming experience mostly follow "paddy + pulses + oilseed" type of cropping pattern with average farm productivity 29.96 qt/ha. The average number of livestock and birds population was 9(nine) per family. Majority of respondents having employment of their family members was ranging from 46.67 per cent to 73.32 per cent. The main sources of employment for majority respondents were "farming" followed by "farming + skilled labour activities". Major flood impacts as perceived by farmers were 'increases dependency on mechanical draught power' followed by 'fodder scarcity for livestock' and 'introduction of new and better breeds of livestock'. "Change in cropping pattern" and "reduced income of farmers" were reported the most immediate economic impacts of flood. Population migration, impacts on health and schooling of children, mental and emotional trauma were also reported as social impact of flood. Environmental impacts such as forest degradation, deteriorated water quality, damage to fish habitat and wild life were perceived as major impacts by farmers. Government and non-government organizations should put sincere efforts to meet the needs of the flood affected farmers by organizing awareness campaign on flood. Strategic efforts should be made by the government policy makers in order to minimize the adverse impacts of flood on the farming community.

\section{Introduction}

Recurring flood is a major challenge in the Flood Prone Areas of Assam. Annually $39.58 \%$ area and around $19,92,727$ population are affected by flood (Annon, 2017-18).
Brahmaputra Valley of Assam is one of the most flood-prone valleys in India. Every year, floods, flash floods, riverbank erosion, and sand deposition on fields demolish the landscape. However, flash floods have become more destructive since the mid 1990s, 
especially on the northern bank of the Brahmaputra valley (Annon, 2010). With time the flood situation got worse and created serious hurdles for the people to survive. Flash flood and erratic submergence regimes are the major limitations in increasing the productivity of rice cultivated in rainfed situation in Assam. Floods, flash flood, river bank erosion and sand casting are the most recurrent water- induced vulnerabilities affecting these areas of Assam. The intensity of flood damages in Assam during 2006 to 2015 is presented in the table 1. All of these hazards have affected the farming society living in the flood prone areas of Assam. Flood pose an increased threat in Assam especially in agriculture sector. Flood has affected the farming community resulting in migration, unemployment, food insecurity, poverty etc. Considering projections for increasing flood impacts, it is important to inform policy makers on the perception of farmer about the causes of flood, its impacts and their sources of employment. Hence, the objectives of the study were to examine level of farmers' perception on the severity of various flood impacts and the employment opportunities in a flood areas of Assam.

\section{Materials and Methods}

The study was conducted in Jorhat and Majuli districts of Upper Brahmaputra valley zone of Assam. A total of 160 farmers were selected from eight villages by proportionate cum random sampling technique. Four villages from each two districts namely Jorhat and Majuli districts were selected purposively by considering number of flood affected farmers. Selected respondents were interviewed personally with the help of specially structured schedule. In order to assess farmer's perception on flood impact a structured schedule was prepared that contains statements regarding flood impact related to various socio economic aspects viz. crop, society, health, transportation, income, livestock and environmental aspect. Responses regarding perception of farmers on flood impact were collected in three point continuum, namely 'Strongly agree', 'Agree' and 'Disagree' with a score of 3,2 and 1 respectively. Weighted Score (WS) and Mean Weighted Score (MWS) was calculated by following formula

$$
\mathrm{WS}=\sum 3 \mathrm{x} f x_{\mathrm{i}}+2 \mathrm{x} f x_{\mathrm{i}}+1 \mathrm{x} f x_{i}
$$

Where, WS $=$ Weighted score

$f x_{\mathrm{i}}=$ frequency of respondents in $\mathrm{i}^{\text {th }}$ statement

\section{MWS $=$}

$$
\sum 3 \mathrm{X} f x_{\mathrm{i}}+2 \mathrm{X} f x_{\mathrm{i}}+1 \mathrm{X} f x_{i}
$$

N

Where, MWS = Mean Weighted score

$f x_{\mathrm{i}}=$ frequency of respondents in $\mathrm{i}^{\text {th }}$ statement

$\mathrm{N}=$ total number of respodents

A pretested research schedule was used for collection of data. Appropriate statistical tools such as frequency, percentage, mean, standard deviation, weighted mean score were used for analysis of data.

\section{Results and Discussion}

\section{Socio economic profile of the respondents}

It is evident from table 2 that majority of the respondents $(60.63 \%)$ belong to age range 41 59 years with education level ranging from primary to middle school level. Family size of 4-6 members was found for majority around $82.50 \%$ farmers. Similar findings were found in the study conducted by Udmale et al., (2014) and Barman et al., (2013). Majority of the farmers were small $(53.13 \%)$ and marginal farmers $(35.00 \%)$ and they mostly follow 
"paddy + pulses + oilseed" type of cropping pattern. Majority $(62.50 \%)$ of the respondents had farming experience for about 13-32 years and rear livestock and birds number of medium size $(80.63 \%)$. As regard to annual income majority of the respondents $(68.13 \%)$ belongs to income range Rs. 48,000.00 to Rs. $1,00,000.00$.

\section{Employment status of farmers}

The table 3 reveals that majority of farmers (59.38 per cent) belonged to the medium category in term employment status followed by low level of employment status (28.12 per cent). Majority of the marginal farmers have medium level of employment status (42.6 per cent).

While in case of small and medium farmers also the employment status was found to be medium as well. The mean value 57.59 indicates average employment status of the farmers was medium level. Only 12.50 percent of respondents had high level employment status.

It also reveals from table 4 that majority $(50.00 \%)$ of the marginal farmers followed "only farming" as their source of employment, followed by "Farming+ skill labour activities" (27.14\%), "Farming +small business" (11.43\%), Farming +skill labour activities + small business (5.71\%), "Farming + daily wage earner" (4.29\%). Very less farmers prefer Farming+ skill labour activities + small business+ daily wage earner (1.43\%).

Similiarly in case of Small and medium farmer majority of the farmers followed "only farming" (41.67\%) and (33.33\%) respectively. However in case of Marginal farmers, the percentage is higher compared to the small and medium category of farmers because the other two category of farmers are actively engaged in other activities as well like skill activity, small business, daily wage activities etc. Therefore, they have multiple source of employment to maintain their financial security. Similar findings were found in the study conducted by Naveen (2014).

\section{Farmers perception on flood impact}

The table 5 depicts the perception of farmers about flood impact. In terms of flood impact on crop, majority $(57.50 \%)$ of the respondents strongly agreed that "flood leads to change in cropping pattern" and "flood results in the outbreak of pest and diseases" (52.50\%). In terms of flood impact on society, majority $(61.88 \%)$ strongly agreed that flood results in migration of hundreds of families and 86.25 percent of the respondents suffered from emotional trauma which reflects in their demotivated attitude and less enthusiasm in work. In terms of flood impact on livestock, majority of the respondents found to be strongly agreed to the statement that "flood increases the dependency on mechanical draught power" (93.75\%) followed by strongly agreed to "flood results in fodder scarcity for livestock"( $81.88 \%)$.

While $50.63 \%$ of the respondents had strongly agreed that flood result in introduction of new and better breeds of livestock. In terms of flood impact on health, majority of respondents strongly agreed that "Flood results in outbreak of contagious diseases" $(95.00 \%)$ followed by "suffered due to heavy medical expenditure during the time of flood" $(88.75 \%)$ and flood results in outbreak of skin diseases $(78.75 \%)$.

In terms of flood impact on income, majority strongly agreed the statement of flood results in reduction of household income (86.88\%). In terms of flood impact on transportation, majority strongly agreed that "Flood disturbs the transport and communication facilities" $(58.75 \%)$. 
Table.1 Year-wise damage caused due to floods in Assam during (2006 - 2015)

\begin{tabular}{|l|c|c|c|}
\hline Year & $\begin{array}{c}\text { Human Mortality } \\
\text { (in no.) }\end{array}$ & $\begin{array}{c}\text { Livestock Mortality } \\
\text { (in No) }\end{array}$ & $\begin{array}{c}\text { Cropped areas affected } \\
\text { (in Lakh ha) }\end{array}$ \\
\hline $\mathbf{2 0 0 6 - 0 7}$ & 7 & 20 & 0.11 \\
\hline $\mathbf{2 0 0 7 - 0 8}$ & 134 & NA & 6.75 \\
\hline $\mathbf{2 0 0 8 - 0 9}$ & NA & NA & NA \\
\hline $\mathbf{2 0 0 9 - 1 0}$ & 8 & 12 & 0.3 \\
\hline $\mathbf{2 0 1 0 - 1 1}$ & 57 & 3623 & 1.87 \\
\hline $\mathbf{2 0 1 1 - 1 2}$ & 13 & NA & 4.17 \\
\hline $\mathbf{2 0 1 2 - 1 3}$ & 168 & 9921 & 3.28 \\
\hline $\mathbf{2 0 1 3 - 1 4}$ & NA & NA & 0.013 \\
\hline $\mathbf{2 0 1 4 - 1 5}$ & 90 & 8961 & 3.67 \\
\hline
\end{tabular}

Source: Department of Agriculture, Govt. of Assam, NA= Data not available

Table.2 Socio economic profile of the respondents $(n=160)$

\begin{tabular}{|c|c|c|c|c|}
\hline & Socio economic profiles & Frequency & Percentage & Mean score \\
\hline \multirow[t]{4}{*}{$\mathbf{A}$} & Age & & & \\
\hline & $22-40$ years & 30 & 18.75 & \\
\hline & $41-59$ years & 97 & 60.63 & 42.55 \\
\hline & $60-77$ years & 33 & 20.63 & \\
\hline \multirow[t]{7}{*}{ B } & Educational Status & & & \\
\hline & Illiterate & 16 & 10.00 & \\
\hline & Primary school level & 51 & 31.90 & \\
\hline & Middle school level & 59 & 36.90 & \\
\hline & High school level & 23 & 14.40 & \\
\hline & Higher secondary level & 6 & 3.80 & \\
\hline & Graduate and above & 5 & 3.10 & \\
\hline \multirow[t]{4}{*}{$\mathbf{C}$} & Family size & & & \\
\hline & Small size (<4 members) & 12 & 7.50 & \\
\hline & Medium size (4-6 members) & 132 & 82.50 & 5.09 \\
\hline & Large size (> 6 members) & 16 & 10.00 & \\
\hline \multirow[t]{4}{*}{ D } & Operational land holding & & & \\
\hline & Marginal(upto 1.0 ha) & 70 & 43.75 & \\
\hline & Small (upto 2.0 ha) & 72 & 45.00 & 1.16 \\
\hline & Medium (upto 4.0 ha) & 18 & 11.25 & \\
\hline \multirow[t]{7}{*}{$\mathbf{E}$} & Cropping pattern & & & \\
\hline & Paddy & 11 & 6.88 & \\
\hline & Paddy+ pulses & 24 & 15.00 & \\
\hline & Paddy+ vegetables & 29 & 18.13 & \\
\hline & Paddy+ oilseeds & 21 & 13.13 & \\
\hline & Paddy+ pulses+ vegetables & 34 & 21.25 & \\
\hline & Paddy + pulses + oilseeds & 41 & 25.63 & \\
\hline \multirow[t]{4}{*}{$\mathbf{F}$} & Farming experience & & & \\
\hline & Low (5-12 years) & 27 & 16.88 & \\
\hline & Medium (13-32 years) & 100 & 62.50 & \\
\hline & High (33-49 years) & 33 & 20.63 & \\
\hline \multirow[t]{4}{*}{ G } & Annual income & & & \\
\hline & Low (0.31-0.47 lakh) & 27 & 16.88 & \\
\hline & Medium (0.48-1 lakh) & 109 & 68.13 & \\
\hline & High (1.01-1.48 lakh) & 24 & 15.00 & \\
\hline \multirow[t]{4}{*}{ H } & Livestock and bird reared & & & \\
\hline & Small (4-8 number) & 19 & 11.88 & \\
\hline & Medium(9-12 number) & 129 & 80.63 & 8.45 \\
\hline & Large(13-15 number) & 12 & 7.50 & \\
\hline
\end{tabular}


Table.3 Farmers category wise employment status in flood affected areas $(\mathrm{n}=160)$

\begin{tabular}{|l|l|l|l|l|l|l|}
\hline \multirow{2}{*}{$\begin{array}{l}\text { Farmers } \\
\text { categories }\end{array}$} & Frequency & \multicolumn{3}{|c|}{ Frequency and percentage of farmers } & Mean & SD \\
\cline { 3 - 6 } & & Low level & $\begin{array}{l}\text { Medium } \\
\text { level }\end{array}$ & High level & & \\
\hline $\begin{array}{l}\text { Marginal } \\
\text { farmers }\end{array}$ & 70 & $25(35.71)$ & $30(42.86)$ & $15(21.43)$ & 57.60 & 23.98 \\
\hline $\begin{array}{l}\text { Small } \\
\text { farmers }\end{array}$ & 72 & $23(31.94)$ & $34(42.22)$ & $15(20.83)$ & 56.55 & 22.03 \\
\hline $\begin{array}{l}\text { Medium } \\
\text { Farmers }\end{array}$ & 18 & $5(27.78)$ & $7(38.89)$ & $6(33.33)$ & 61.02 & 25.64 \\
\hline Total & 160 & $45(28.12)$ & $95(59.38)$ & $20(12.50)$ & 57.51 & 23.19 \\
\hline
\end{tabular}

Figure in parenthesis indicates percentage

Table.4 Farmers category wise source of employment in flood affected areas $(n=160)$

\begin{tabular}{|l|l|l|l|}
\hline Farmers categories & \multicolumn{3}{|c|}{ Frequency and percentage of farmers } \\
\cline { 2 - 4 } & Marginal farmer & Small farmer & Medium farmer \\
\hline Only farming & $35(50.00)$ & $30(41.67)$ & $6(33.33)$ \\
\hline $\begin{array}{l}\text { Farming +skill labour } \\
\text { activities }\end{array}$ & $19(27.14)$ & $23(31.94)$ & $5(27.78)$ \\
\hline $\begin{array}{l}\text { Farming +small } \\
\text { business }\end{array}$ & $8(11.43)$ & $10(13.89)$ & $4(22.22)$ \\
\hline $\begin{array}{l}\text { Farming +daily wage } \\
\text { earner }\end{array}$ & $3(4.29)$ & $6(8.33)$ & $2(11.11)$ \\
\hline $\begin{array}{l}\text { Farming +skill labour } \\
\text { activities + small } \\
\text { business }\end{array}$ & $4(5.71)$ & $3(4.17)$ & $1(5.56)$ \\
\hline $\begin{array}{l}\text { Farming+ skill labour } \\
\text { activities + small } \\
\text { business+ daily wage } \\
\text { earner }\end{array}$ & $1(1.43)$ & 0 & 0 \\
\hline Total (n= 160) & 70 & 72 & 18 \\
\hline
\end{tabular}


Table.5 Farmer's perception on flood impact $(\mathrm{n}=160)$

\begin{tabular}{|c|c|c|c|c|c|c|c|}
\hline \multirow[t]{2}{*}{$\begin{array}{l}\text { Sl. } \\
\text { No. }\end{array}$} & \multirow[t]{2}{*}{ Statements } & \multicolumn{3}{|c|}{$\begin{array}{l}\text { Percentage } \\
\text { respondents }\end{array}$} & \multirow[t]{2}{*}{ WS } & \multirow[t]{2}{*}{ WMS } & \multirow[t]{2}{*}{ RANK } \\
\hline & & & A & DA & & & \\
\hline 1 & Flood leads to change in cropping pattern & 57.50 & 33.13 & 9.38 & 397 & 2.48 & XI \\
\hline 2 & $\begin{array}{l}\text { Flood results in the outbreak of pest and } \\
\text { diseases in the crop field }\end{array}$ & 52.50 & 36.88 & 10.63 & 387 & 2.42 & XIII \\
\hline 3 & $\begin{array}{l}\text { Flood displaced hundreds of families } \\
\text { resulting in migration }\end{array}$ & 61.88 & 19.38 & 18.75 & 389 & 2.43 & XII \\
\hline 4 & $\begin{array}{l}\text { Crop failure due to flood results in food } \\
\text { scarcity }\end{array}$ & 15.00 & 71.88 & 13.13 & 323 & 2.02 & XX1 \\
\hline 5 & $\begin{array}{l}\text { Flood results in the destruction of houses } \\
\text { leading to inadequate shelter facilities }\end{array}$ & 70.00 & 18.75 & 11.25 & 428 & 2.67 & VIII \\
\hline 6 & $\begin{array}{l}\text { Flood hampers the grain storages resulting } \\
\text { in increase in maintenance cost and food } \\
\text { shortage }\end{array}$ & 41.25 & 47.50 & 11.25 & 368 & 2.30 & XVI \\
\hline 7 & $\begin{array}{l}\text { Flood causes an emotional trauma affecting } \\
\text { people's mental health. }\end{array}$ & 86.25 & 3.75 & 10.00 & 412 & 2.58 & $\mathbf{X}$ \\
\hline 8 & $\begin{array}{l}\text { Flood in results in occupational shift from } \\
\text { agricultural sector to non-agricultural sector }\end{array}$ & 13.13 & 37.50 & 49.38 & 262 & 1.64 & XXII \\
\hline 9 & Flood increases the school drop out & 10.63 & 26.88 & 62.50 & 237 & 1.48 & XXIV \\
\hline 10 & Flood results in fodder scarcity for livestock & 81.88 & 0 & 18.13 & 422 & 5.28 & II \\
\hline 11 & $\begin{array}{l}\text { Flood increases the dependency on } \\
\text { mechanical draught power }\end{array}$ & 93.75 & 1.25 & 5.00 & 462 & 5.78 & I \\
\hline 12 & $\begin{array}{l}\text { Flood results in introduction of new and } \\
\text { better breeds of livestock }\end{array}$ & 50.63 & 30.63 & 18.75 & 371 & 4.64 & III \\
\hline 13 & Flood results in outbreak of skin diseases & 78.75 & 3.75 & 17.50 & 418 & 2.61 & IX \\
\hline 14 & $\begin{array}{l}\text { Flood results in outbreak of contagious } \\
\text { diseases }\end{array}$ & 95.00 & 1.88 & 3.13 & 467 & 2.92 & IV \\
\hline 15 & Flood increases the medical expenditure & 88.75 & 6.25 & 5.00 & 454 & 2.84 & VI \\
\hline 16 & $\begin{array}{l}\text { Flood results in reduction of household } \\
\text { income }\end{array}$ & 86.88 & 0 & 13.13 & 438 & 2.74 & VII \\
\hline 17 & $\begin{array}{l}\text { Flood results in reduction in spending on } \\
\text { festivals }\end{array}$ & 41.88 & 36.88 & 21.25 & 353 & 2.21 & XVIII \\
\hline 18 & Increased transportation cost & 47.50 & 14.38 & 38.13 & 335 & 2.09 & $\mathbf{X X}$ \\
\hline 19 & $\begin{array}{l}\text { Disturbs the transport and communication } \\
\text { facilities }\end{array}$ & 58.75 & 18.75 & 22.50 & 378 & 2.36 & XIV \\
\hline 20 & $\begin{array}{l}\text { Soil erosion and river bank erosion is caused } \\
\text { by heavy flood }\end{array}$ & 92.50 & 0 & 7.50 & 456 & 2.85 & V \\
\hline 21 & Sedimentation increases soil fertility & 41.88 & 33.75 & 24.38 & 348 & 2.18 & XIX \\
\hline 22 & $\begin{array}{l}\text { Water turbidity due to flood degrade the } \\
\text { water quality }\end{array}$ & 59.38 & 15.63 & 25.00 & 375 & 2.34 & $\mathbf{X V}$ \\
\hline 23 & $\begin{array}{l}\text { Flood can affect the health and well-being } \\
\text { of wildlife }\end{array}$ & 51.25 & 18.75 & 30.00 & 354 & 2.22 & XVII \\
\hline 24 & $\begin{array}{l}\text { Hibernation pattern of some wildlife } \\
\text { creatures is disturbed due to flood }\end{array}$ & 24.38 & 12.50 & 63.13 & 258 & 1.61 & XXIII \\
\hline
\end{tabular}

$\mathrm{SA}=$ Strongly agree, $\mathrm{A}=$ Agree, $\mathrm{DA}=$ Disagree, $\mathrm{WS}=$ Weighted Score, WMS= Weighted Mean Score 
In terms of flood impact on environment, majority $(92.50 \%)$ strongly agreed that soil erosion and river bank erosion is caused by heavy flood" and 59.38\% respondents strongly agreed to the statement that "water turbidity due to flood degrade the water quality" while flood can affect the health and well-being of wildlife was strongly agreed by $51.25 \%$ respondents. Out of 24 statements on flood impact "Flood increases the dependency on mechanical draught power" hold the position of rank I (5.78) followed by "Flood results in fodder scarcity for livestock" (5.28). "Flood results in introduction of new and better breeds of livestock" hold the rank III (4.64) which indicates that farmers strongly agree to these statements.

Flood threatened the agrarian economy of Assam and caused considerable social and economic impacts on farming communities. Farmers were aware of flood and also well perceived the various socio-economic and environmental impacts of flood in the Upper Brahmaputra Valley Zone of Assam. Failure of agriculture subsequently resulted in lack of employment for unskilled laborers, which weakened their livelihood situation and financial situation of farmers. Poor farmers affected by flood could not afford to participate in the celebration of festivals. Environmental impacts of drought were perceived to be high to very high. Majority of the respondents were found to be engaged with "only farming", therefore efforts should be made in organizing awareness programmes about the benefits of multiple cropping. Introduction of crops that can withstand waterlogged condition and flood resistance varieties of crops should be explored as a way of increasing resilience against flood. Government and non-government organizations should put sincere efforts to meet the needs of the flood affected farmers by organizing awareness campaign on flood. Strategic efforts should be made by the government policy makers in order to minimize the adverse impacts of flood on the farming community.

\section{Acknowledgements}

Authors are grateful to farmers of the study area for providing necessary cooperation and support to conduct the study.

\section{References}

Anonymous (2006). District Agricultural Development Strategy, Agricultural Technology Management Agency, Jorhat.

Anonymous (2010). Assam State Disaster Management Policy 2010, ASDMA, Govt of Assam.

Anonymous (2017-18). Economic Survey of Assam, Transformation and Development Department, Government of Assam.

Barman, S. Pathak, K. and Pathak, P.K. (2013). Training need of Tribal farmers in Rapeseed production technology of Upper Brahmaputra Valley Zone of Assam. $J$. Acad. Indus. Res., 1(11): 686-688.

Naveen. V (2014). Livelihood issues in flood affected farm economy: A case study of Don River Basin, Bijapur district. University of Agricultural Sciences Dharwad, Department of Agricultural Economics.

Sing, R. and Singh, U. (2001). Socio economic profile of migrant rural labourers. Indian. J. Ext. Edu., 37(3 \& 4): 159-163.

Udmale, P., Ichikawa, Y., Manandhar, S., Ishidiara, H. and Kiem, A. (2014). Farmers' perception of drought impacts, local adaptation and administrative mitigation measures in Maharashtra State, India. International Journal of Disaster Risk Reduction, 10: 250-269.

\section{How to cite this article:}

Rahman, A. and Barman, S. 2019. Perception on Flood Impact and Source of Employment of Farmers in Flood Affected Areas of Assam. Int.J.Curr.Microbiol.App.Sci. 8(07): 645-651. doi: https://doi.org/10.20546/ijcmas.2019.807.080 